Jurnal Ners Indonesia, Vol. 9, No. 1, September 2018

\title{
PENGETAHUAN DAN SIKAP IBU DENGAN PEMBERIAN IMUNISASI VAKSIN DT PADA BULAN IMUNISASI ANAK SEKOLAH
}

\author{
Yuliani Putri Pratiwi ${ }^{1}$, Mitra $^{2}$, Erna Marni ${ }^{3}$ \\ ${ }^{1}$ PSIK STIKes Hang Tuah Pekanbaru, ${ }^{2}$ Prodi Magister Kesehatan Masyarakat STIKes Hang Tuah Pekanbaru, \\ ${ }^{3}$ PSIK STIKes Hang Tuah Pekanbaru \\ Program Studi Ilmu Keperawatan STIKes Hang Tuah Pekanbaru Jalan Mustafa Sari No 5 Tangkerang Selatan \\ Pekanbaru \\ Telepon 081270087634 Email: putripratiwiqueenza@gmail.com
}

\begin{abstract}
ABSTRAK
Difteri dapat menyebabkan kematian karena menyerang saluran pernapasan dengan menimbulkan sesak napas. Difteri dapat dicegah melalui pemberian imunisasi vaksin DT. Cakupan imunisasi DT di Kota Pekanbaru masih rendah yaitu 73,89\%. Penelitian ini bertujuan untuk mengetahui hubungan pengetahuan dan sikap dengan pemberian imunisasi vaksin difteri tetanus (DT) di Wilayah Kerja Puskesmas Lima Puluh Kota Pekanbaru. Jenis penelitian adalah kuantitatif dengan desain cross sectional menggunakan teknik sampling systematic random sampling dengan menyebarkan kueioner sebanyak 193 kueisioner kepada ibu yang memiliki anak kelas $1 \mathrm{SD}$, analisis data menggunakan uji chi-square. Proporsi imunisasi vaksin DT yaitu 79,8\%, sebagian besar ibu memiliki pengetahuan baik sebanyak $63,2 \%$ dan sikap positif sebanyak $75,1 \%$. Hasil bivariat didapatkan adanya hubungan pengetahuan dengan pemberian imunisasi vaksin DT ( $p$ value: 0,008$)$ dan tidak terdapat hubungan sikap dengan pemberian imunisasi vaksin DT (Pvalue: 0,455). Untuk itu, kepada tenaga kesehatan disarankan memberikan penyuluhan kesehatan tentang manfaat imunisasi vaksin DT, kandungan, waktu, dan durasi pemberian vaksin DT kepada ibu yang memiliki anak usia sekolah untuk meningkatkan status kelengkapan imunisasi.
\end{abstract}

Kata Kunci: Imunisasi Vaksin DT, Pengetahuan dan Sikap

\begin{abstract}
Diphtheria can cause death because it attacks the respiratory tract by causing shortness of breath. Diphtheria can be prevented by giving DT vaccine immunization. DT immunization coverage in Pekanbaru City is still low at 73.89\%. This study aims to determine the relationship of knowledge and attitudes with the provision of immunization for diphtheria tetanus vaccine (DT) in the Working Area of Fifty Cities Pekanbaru Health Center. The type of research is quantitative with design cross sectional using systematic random sampling sampling technique by distributing 193 questionnaires to mothers who have grade 1 elementary school children, analyzing the data using the test chi-square. The proportion of DT vaccine immunization is $79.8 \%$, most mothers have good knowledge of $63.2 \%$ and positive attitudes as much as $75.1 \%$. Results of bivariate correlation knowledge with DT vaccine immunization (pvalue:0.008) and there was no correlation with the attitude of DT vaccine immunization(pvalue:0.455). For this reason, health professionals are advised to provide health education about the benefits of DT vaccine immunization, the content, time and duration of DT vaccine administration to mothers who have school-age children to improve their immunization status.
\end{abstract}

Keywords: Attitude, DT vaccine immunization, Knowledge

\section{PENDAHULUAN}

Difteri merupakan suatu penyakit yang menyerang saluran pernapasan yang akan berakibat kematian jika tidak diberikan penolongan secara tepat. Difteri akan menimbulkan gejala awal berupa sakit di tenggorokan, sesak napas bahkan meningkatnya denyut jantung.

November dan Desember 2017 terjadi peningkatan jumlah kasus difteri di Pekanbaru, 
Yuliani Putri Pratiwi ${ }^{1,}$ Mitra $^{2}$, Erna Marni ${ }^{3}$, Pengetahuan Dan Sikap Ibu Dengan Pemberian Imunisasi Vaksin Dt Pada Bulan Imunisasi Anak Sekolah

ditemukan angka kasus difteri yang terjadi di Pekanbaru sebesar 8 kasus dengan jumlah meninggal 0 kasus (Dinas Kesehatan Kota Pekanbaru, 2018). Difteri sendiri sebenarnya dapat dicegah dengan cara pemberian imunisasi. Saat ini vaksin yang akan digunakan untuk imunisasi rutin dan imunisasi lanjutan guna mencegah penyakit Difteri.

Hasil laporan Dinas Kesehatan Kota Pekanbaru pada tahun 2016, persentase anak kelas 1 SD yang mendapatkan imunisasi DT pada triwulan ke IV dari 20 Puskesmas yang ada di Kota Pekanbaru berjumlah 15.563 anak (73,89\%) hasil ini masih cukup rendah dari target pencapaian pemberian imunisasi DT yaitu 98\%. Dari laporan hasil BIAS yang dilakukan 20 puskesmas yang ada di Pekanbaru didapatkan hasil pencapaian pemberian imunisasi vaksin DT terendah adalah Puskesmas Lima Puluh dengan sasaran target hanya mencapai 54,24\% (Dinas Kesehatan Kota Pekanbaru, 2016)

Rendahnya pencapaian target dari imunisasi menyebabkan terjadinya penurunan angka Drop Out (DO) pada imunisasi. Hal ini dikarenakan tidak jarang banyak dijumpai orangtua yang ragu atau bahkan menolak memberikan imunisasi pada anaknya dengan berbagai alasan seperti ketakutan atau penolakan imunisasi disebabkan oleh pandangan religi bahwa vaksin tersebut haram karena mengandung unsur babi.

Menurut hasil penelitian yang dilakukan oleh Izza, Lestari dan Tumaji (2017) dengan judul faktor orang tua dan status imunisasi dpt anak 12-36 bulan di Kecamatan Ketapang dan Kecamatan Sokobanah Kabupaten Sampang terdapat sebagian orang tua yang bersikap kurang baik mengenai imunisasi yang memiliki risiko 0,05 kali bahwa anaknya yang berusia 12-36 bulan tidak mendapat imunisasi DPT. Faktor sikap kurang baik ini ditunjukkan dengan tidak mau memberikan imunisasi kembali kepada anak karena setelah imunisasi badan anak akan menjadi panas. Jadi sesudah DPT 1 orang tua tidak mau kembali untuk membawa anaknya imunisasi DPT 2 dan DPT 3. Sikap responden berpengaruh signifikan terhadap perilaku kesediaan responden untuk mengimunisasi DPT anaknya.

Berdasarkan latar belakang diatas peneliti tertarik melakukan penelitian yang berjudul "Hubungan Pengetahuan dan Sikap Ibu dengan Pemberian Imunisasi Vaksin DT pada Bulan Imunisasi Anak Sekolah di Wilayah Kerja Puskesmas Lima Puluh Kota Pekanbaru, Riau".

\section{METODE PENELITIAN}

Jenis penelitian yang digunakan adalah kuantitatif dengan desain pendekatan cross sectional. Sampel dalam penelitian ini adalah anak kelas 1 SD dengan yang menjadi respondennya adalah ibu yang memiliki anak kelas 1 SD. Dilakukan penelitian di Wilayah Kerja Puskesmas Lima Puluh karena tidak tercapainya target imunisasi yang dipengaruhi banyak orang tua yang tidak mau memberikan imunisasi vaksin DT tanpa alasan yang jelas. 
Populasi pada penelitian ini adalah seluruh anak kelas 1 SD dari 5 SD Negeri yang ada di wilayah kerja Puskesmas Lima Puluh Kota Pekanbaru yang berjumlah 229 orang dengan total sample sebanyak 193 responden. Pengambilan sampel menggunakan teknik Systematic Random Sampling.

Alat pengumpulan data menggunakan kuesioner pengukuran pengetahuan dan sikap, hasil uji validitas dari 15 pertanyaan pengetahuan ibu mengenai imunisasi diperoleh semua pertanyaan valid berada pada rentang $r$ hasil $(0,419-0,788)$, untuk penyataan sikap dari 15 pernyataan diperoleh 13 pernyataan valid berada pada rentang $r$ hasil $(0,426-0,702)$ dan 2 pernyataan tidak valid pada rentang $r$ hasil (0,310-0,325). Reabilitas pada penelitian ini didapatkan untuk kuesioner pengetahuan nilai alpha 0,881 dan untuk kuesioner sikap didapatkan nilai alpha 0,874 , maka dapat disimpulkan bahwa kuesioner reliabel karna nilai cronbach alpha lebih dari 0,6.

Analisa data dilakukan secara univariat untuk melihat gambaran pengetahuan, gambaran sikap dan gambaran pemberian imunisasi vaksin tetanus difteri pada bulan imunisasi anak sekolah, dan bivariat untuk mengetahui apakah adanya hubungan independen (pengetahuan dan sikap) dan vatiabel dependen (pemberian imunisasi vaksin difteri tetanus pada Bulan Imunisasi Anak Sekolah).

\section{HASIL PENELITIAN}

Analisa Univariat

\section{Karakteristik Responden}

Tabel 1.

Distribusi Frekuensi Responden Berdasarkan Karakteristik Ibu

\begin{tabular}{llcc}
\hline Karakteristik Responden & Frekuensi (n) & Persentase (\%) \\
\hline Umur & & \\
Mean & 34,97 tahun & & \\
Std.Deviation & 5,264 tahun & - & - \\
Min & 26 tahun & & \\
Max & 48 tahun & & \\
\hline Pekerjaan Ibu & Tidak Bekerja & 170 & 88,1 \\
& Bekerja & 23 & 11,9 \\
\hline Pendidikan Ibu & SD & 13 & 6,7 \\
& SMP & 40 & 20,7 \\
& SMA & 109 & 56,5 \\
& Perguruan Tinggi & 31 & 16,1 \\
& & & \\
\hline
\end{tabular}

Berdasarkan tabel 1 dapat disimpulkan bahwa pendidikan ibu terdistribusi dari SD sampai Perguruan Tinggi dengan proporsi terbanyak adalah SMA (56,5\%) dan hanya sebagian kecil ibu yang berpendidikan SD (6,7\%). Untuk perkerjaan pada umumnya adalah tidak bekerja atau ibu rumah tangga yaitu sebanyak $88,1 \%$.

\section{Pemberian Imunisasi}

\section{Gambar 1.}

Distribusi Frekuensi Pemberian Imunisasi Vaksin DT pada Bulan Imunisasi Anak Sekolah

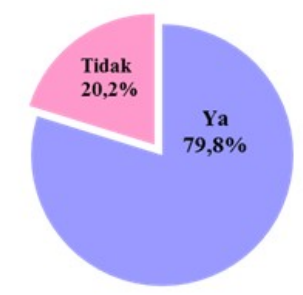

Berdasarkan gambar 1 diperoleh lebih dari separuh ibu yang memberikan imunisasi vaksin DT pada anak yaitu sebanyak 79,8\%.

\section{Pengetahuan}

\section{Gambar 2.}


Yuliani Putri Pratiwi ${ }^{1,}$ Mitra $^{2}$, Erna Marni ${ }^{3}$, Pengetahuan Dan Sikap Ibu Dengan Pemberian Imunisasi Vaksin Dt Pada Bulan Imunisasi Anak Sekolah

Distribusi frekuensi Pengetahuan Ibu dalam Pemberian Vaksin DT pada Bulan Imunisasi Anak Sekolah

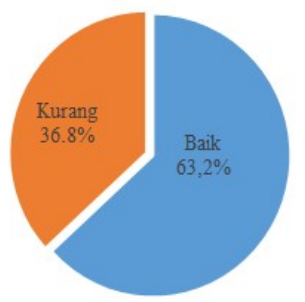

Berdasarkan gambar 2 menunjukkan lebih dari separuh ibu yang memiliki pengetahuan yang baik dengan pemberian imunisasi vaksin DT yaitu sebanyak (63,2\%).

4. Sikap

\section{Gambar 3.}

Distribusi Frekuensi Sikap Ibu dalam Pemberian Vaksin DT pada Bulan Imunisasi Anak Sekolah

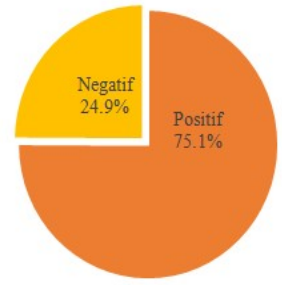

Berdasarkan gambar 3 menunjukkan lebih dari separuh ibu yang memiliki sikap yang positif dalam pemberian imunisasi vaksin DT pada anak.

\section{Analisa Bivariat}

1. Hubungan

Pengetahuan dengan

Pemberian Imunisasi Vaksin DT

\section{Tabel 2.}

Hubungan Pengetahuan dengan Pemberian Imunisasi Vaksin DT

\begin{tabular}{|c|c|c|c|c|c|c|c|}
\hline \multirow{3}{*}{ Pengetahuan } & \multicolumn{6}{|c|}{ Pemberian Imunisasi DT } & \multirow{3}{*}{$\underset{\text { value }}{p}$} \\
\hline & \multicolumn{2}{|c|}{ Tidak } & \multicolumn{2}{|c|}{$\mathrm{Ya}$} & \multicolumn{2}{|c|}{ Total } & \\
\hline & n & $\%$ & n & $\%$ & n & $\%$ & \\
\hline Kurang & 22 & 31,0 & 49 & 69,0 & 71 & 100,0 & 0,008 \\
\hline Baik & 17 & 13,9 & 105 & 86,1 & 122 & 100,0 & \\
\hline Total & 39 & 20,2 & 154 & 79,8 & 193 & 100,0 & \\
\hline
\end{tabular}

Berdasarkan tabel 2 proporsi pengetahuan kurang yang tidak memberikan imunisasi DT adalah sebanyak 31.0\%, sedangkan untuk pengetahuan baik yang tidak memberikan imunisasi DT adalah sebanyak 13,9\%. Dengan demikian proporsi ibu yang pengetahuan kurang lebih tinggi dibandingkan dengan ibu yang berpengetahuan baik. Berdasarkan hasil uji chi-square didapatkan $p$ value $0,008<0,05$, dapat disimpulkan bahwa H0 ditolak maka hal ini menunjukkan terdapat hubungan pengetahuan dengan pemberian imunisasi vaksin DT.

2. Hubungan Sikap dengan Pemberian Imunisasi Vaksin DT

Tabel 3.

Hubungan Sikap dengan Pemberian Imunisasi Vaksin DT

\begin{tabular}{|c|c|c|c|c|c|c|c|}
\hline \multirow{3}{*}{ Sikap } & \multicolumn{6}{|c|}{ Pemberian Imunisasi DT } & \multirow{3}{*}{$\begin{array}{c}p \\
\text { value }\end{array}$} \\
\hline & \multicolumn{2}{|c|}{ Tidak } & \multicolumn{2}{|c|}{$\mathrm{Ya}$} & \multicolumn{2}{|c|}{ Total } & \\
\hline & $\mathrm{n}$ & $\%$ & $\mathrm{n}$ & $\%$ & $\mathrm{n}$ & $\%$ & \\
\hline Negatif & 12 & 25,0 & 36 & 75,0 & 48 & 100,0 & 0,455 \\
\hline Positif & 27 & 18,6 & 118 & 81,4 & 145 & 100,0 & \\
\hline Total & 39 & 20,2 & 154 & 79,8 & 193 & 100,0 & \\
\hline
\end{tabular}

Berdasarkan tabel 3 proporsi sikap negatif yang tidak memberikan imunisasi vaksin DT sebesar 25,0\%, sedangkan sikap positif yang tidak memberikan imunisasi vaksin DT sebesar 18,6\%. Dengan demikian proporsi sikap ibu yang negatif tidak memberikan imunisasi lebih tinggi dari sikap positif yang tidak memberikan imunisasi. Berdasarkan hasil uji chi-square didapatkan $p$ value $=0,455>0,05$ dapat disimpulkan $\mathrm{H} 0$ diterima maka hal ini menunjukkan tidak 
terdapat hubungan sikap dengan pemberian imunisasi vaksin DT. Dengan demikian sikap negatif cenderung tidak memberikan imunisasi vaksin DT.

\section{PEMBAHASAN}

\section{Pemberian Imunisasi}

Pemberian imunisai berdasarkan pengumpulan data didapatkan banyak ibu yang memberikan imunisasi kepada anaknya. Hal ini berarti adanya peningkatan capaian imunisasi di Puskesmas Lima Puluh sebanyak $25,56 \%$ dari pencapaian sebelumnya $(54,24 \%)$. Target imunisasi vaksin DT di Provinsi Riau adalah 98\%.

Dengan demikian berdasarkan hasil penelitian target imunisasi vaksin DT di Wilayah Puskesmas Lima Puluh masih berada dibawah target sasaran pemberian imunisasi vaksin DT pada bulan imunisasi anak sekolah.

Penelitian ini sejalan dengan penelitian Emilya \& Lestari (2017), dari 40 responden sebanyak 25 responden (62,5\%) yang tidak memberikan imunisasi pada anak. Menurut peneliti untuk meningkatkan target imunisasi vaksin DT adalah dengan memberikan penyuluhan mengenai pemberian imunisasi agar membuat ibu mengetahui pentingnya imunisasi bagi anak guna mencegah penyakit difteri.

\section{Pengetahuan dengan Pemberian}

\section{Imunisasi Vaksin DT}

Berdasarkan hasil analisis bivariat penelitian yang dilakukan terhadap $193 \mathrm{ibu}$ yang berada di Wilayah Kerja Puskesmas Lima Puluh Kota Pekanbaru didapatkan hasil uji chi-square $p$ value $=0,008<0,05$. Hal ini berarti ada hubungan antara pengetahuan dengan pemberian imunisasi vaksin DT.

Hasil penelitian ini diperoleh $86,1 \%$ ibu yang berpengetahuan baik dan sudah memberikan imunisasi vaksin DT pada anak, dan sebanyak $31,0 \%$ ibu berpengetahuan kurang yang tidak memberikan imunisasi vaksin DT pada anak. Berdasarkan distribusi pertanyaan kuesioner masih banyak ibu yang menjawab salah pada pertanyaan yang diberikan, ibu tidak mengetahui bahwa apa kandungan dari vaksin DT yang diberikan kepada anak sebanyak $75,1 \%$, ibu yang tidak tahu atau tidak ingat kapan anak akan diberikan imunisasi vaksin DT sebanyak $79,8 \%$, serta ibu yang tidak mengetahui berapa kali anak akan mendapatkan imunisasi lanjutan disekolah sebanyak $66,3 \%$.

Dengan demikian dapat disimpulkan masih banyak ibu yang tidak perduli terhadap status kelengkapan imunisasi yang didapatkan pada anak. Ibu yang berpengetahuan kurang 2 kali lebih berisiko untuk tidak lagi memberikan imunisasi selanjutnya pada anak.

Penelitian ini sejalan dengan Riyanto (2013), didapatkan hasil $p$ value $=0,00$ yang menunjukkan adanya hubungan pengetahuan ibu dengan perilaku pelaksanaan imunisasi pada balita. Ibu yang memiliki pengetahuan baik lebih cenderung mempunyai perilaku untuk memberikan imunisasi lengkap terhadap balita. 
Yuliani Putri Pratiwi ${ }^{1,}$ Mitra $^{2}$, Erna Marni ${ }^{3}$, Pengetahuan Dan Sikap Ibu Dengan Pemberian Imunisasi Vaksin Dt Pada Bulan Imunisasi Anak Sekolah

Hasil penelitian ini didapatkan bahwa sebagian besar pendidikan yang dimiliki oleh ibu adalah SMA (56,5\%). Pendidikan akan memberikan pengaruh terhadap cara berpikir dan pengambilan keputusan yang akan diambil oleh seseorang. Dengan pendidikan tinggi diharapkan seseorang akan memiliki pengetahuan yang semakin luas. Namun, peningkatan pengetahuan tidak selamanya didapatkan melalui pendidikan formal saja, akan tetapi juga dapat dipengaruhi oleh pendidikan non formal (Wawan \& Dewi, 2010).

Hasil penelitian ini juga diketahui sebagian besar ibu berada pada rata-rata umur 34 tahun sebanyak 30,1\%. Umur akan mempengaruhi tingkat kematangan dan kekuatan seseorang dalam berfikir. Penelitian ini sejalan dengan hasil penelitian Supriatin (2015), bahwa dari 86 responden didapatkan 42 orang responden $(48,84 \%)$ berada pada usia 20-35 tahun. Hal ini menunjukkan bahwa pola pikir dari seseorang sudah dewasa akan mempengaruhi tingkat pengetahuan. Pengetahuan akan membuat seseorang untuk berfikir dan berusaha dalam menentukan suatu tindakan, serta emosi akan bekerja sebagai reaksi perlakuan yang akan terjadi (Notoatmodjo, 2011).

Menurut penelitian Anton (2014), status pekerjaan ibu akan mempengaruhi kesempatan dan waktu untuk mencari tahu mengenai informasi dari imunisasi. Ibu dengan pekerjaan sebagai ibu rumah tangga memiliki peluang lebih besar untuk mencari tahu informasi mengenai imunisasi melalui media informasi seperti televisi, radio dan surat kabar.

Berdasarkan hasil penelitian yang dilakukan, jurnal serta teori diatas argumen peneliti bahwa ketika umur belum dewasa akan mempengaruhi pengetahuan. Belum matangnya umur ibu akan lebih cenderung membuat ibu tidak memberikan imunisasi kepada anak. Sehingga anak akan lebih besar beresiko untuk tidak mendapatkan imunisasi DT atau imunisasi lanjutan dan pekerjaan akan mempengaruhi ibu untuk mencari tahu informasi mengenai imunisasi serta mempengaruhi kesediaan waktu untuk pemberian imunisasi kepada anak sesuai jadwalnya.

\section{Sikap dengan Pemberian Imunisasi Vaksin DT}

Berdasarkan hasil analisis bivariat penelitian yang dilakukan terhadap $193 \mathrm{ibu}$ yang berada di Wilayah Kerja Puskesmas Lima Puluh Kota Pekanbaru didapatkan hasil uji chi-square diperoleh $p$ value $=0,455>$ 0,05 , hal ini berarti tidak adanya hubungan antara sikap dengan pemberian imunisasi vaksin DT.

Hasil penelitian ini diperoleh 75,0\% ibu memiliki sikap negatif dan sudah memberikan imunisasi vaksin DT kepada anak, 25,0\% untuk ibu yang sikap negatif yang tidak memberikan imunisasi vaksin DT pada anak. 
Berdasarkan data distribusi pernyataan kuesioner tentang pemberian imunisasi vaksin DT, dari pernyataan tersebut sebagian besar masih banyak ibu yang keberatan untuk memberikan imunsasi vaksin DT (14,5\%), ibu beranggapan penyakit yang yang dicegah imunisasi bukan penyakit yang berbahaya (31,1\%), ibu merasa tidak perlu memberikan imunisasi vaksin DT (5,2\%), apabila anak mendapatkan vaksin DT akan memberikan efek samping yang sangat berbahaya dari penyakit difteri itu sendiri $(9,8 \%)$ dan ibu beranggapan imunisasi vaksin DT akan berpengaruh buruk terhadap pertumbuhan $(6,2 \%)$.

Dengan demikian, banyak ibu yang tidak mau lagi memberikan imunisasi lanjutan kepada anak. Diharpakan dukungan keluarga akan lebih membantu ibu untuk memberikan kesadaran dalam pemberian imunisasi pada anak. Penelitian ini membuktikan bahwa ibu yang memiliki sikap negatif memiliki kecenderungan 1 kali lebih beresiko untuk tidak memberikan imunisasi selanjutnya pada anak. Pemberian imunisasi dasar lengkap lebih banyak ditemukan pada ibu yang memiliki sikap postiif $(51,7 \%)$ dibandingkan dengan sikap negatif $(0 \%)$.

Secara teori sikap sendiri adalah kesadaran yang menentukan suatu tindakan nyata atau tidak nyata dari seseorang dalam kehidupan sehari-hari. Sikap didasari oleh kemampuan berpikir dan pemahaman yang tepat tentang suatu objek untuk terbentuknya sikap dan perlakuan yang sesuai. (Wawan \& Dewi, 2010).

Menurut penelitian yang dilakukan oleh Riyanto (2013), rendahnya pengetahuan yang dimiliki ibu akan membuat sikap ibu negatif karena rendahnya pendidikan akan kesulitan dalam penerimaan informasi yang didapatkan. Sosial budaya juga mempengerauhi ibu dalam peningkatan status imunisasi, sebagian ibu berpendapat dengan diberikannya imunisasi anak akan menjadi sakit bahkan meninggal dunia. Pandangan dan keyakinan inilah yang membentuk sikap negatif maupun sikap positif yang akan diberikan ibu kepada anak.

Berdasarkan argumen peneliti dilihat dari hasil kuesioner, responden mencari tahu informasi mengenai imunisasi yang akan diberikan kepada anak. Sehingga sebagian besar banyak responden yang memiliki sikap positif akan tetapi tidak memiliki keinginan untuk memberikan imunisasi lanjutan kepada anak. Ibu butuh informasi mengenai imunisasi vaksin DT dan dukungan keluarga sebagai penyemangat ibu guna meningkatkan status imunisasi vaksin DT pada anak.

\section{SIMPULAN}

Ibu di Wilayah Kerja Puskesmas Lima Puluh memiliki pengetahuan baik dengan mayoritas memiliki sikap positif dan sebagian besar tidak berkeinginan memberikan imunisasi vaksin DT pada anak.

\section{SARAN}


Yuliani Putri Pratiwi ${ }^{1,}$ Mitra $^{2}$, Erna Marni ${ }^{3}$, Pengetahuan Dan Sikap Ibu Dengan Pemberian Imunisasi Vaksin Dt Pada Bulan Imunisasi Anak Sekolah

Tenaga kesehatan disarankan Medika.

memberikan penyuluhan kesehatan tentang manfaat imunisasi vaksin DT, kandungan, waktu, dan durasi pemberian vaksin DT kepada ibu yang memiliki anak usia sekolah untuk meningkatkan status kelengkapan imunisasi

\section{DAFTAR PUSTAKA}

Anton, A. (2014). Gambaran pengetahuan, sikap, dan perilaku ibu tentang pembrian imunisasi dasar lengkap pada bayi di wilayah kerja puskesmas sealong kecamatan sekadu hilir kabupaten sekadu. Fakultas Kedokteran Universitas Tanjungpura Pontianak Naskah Publikasi.

Emilya, S., \& Lestari, Y. (2017). Artikel penelitian hubungan pengetahuan dan sikap ibu balita terhadap tindakan imunisasi dasar lengkap di kelurahan lambung bukit kota padang tahun 2014 . Jurnal Kesehatan Andalas, 6(2), 386390.

Dinas Kesehatan Kota Pekanbaru. (2016). Profil kesehatan kota pekanbaru 2016. Pekanbaru: Dinas Kesehatan Kota Pekanbaru

Dinas Kesehatan Kota Pekanbaru. (2018). Profil kesehatan kota pekanbaru 2017. Pekanbaru: Dinas Kesehatan Kota Pekanbaru.

Notoatmodjo, S. (2011). Kesehatan masyarakat ilmu \& seni (2nd ed., Vol. 2). Jakarta: Rineka Cipta.

Riyanto, A. D. (2013). Perilaku pelaksanaan imunisasi dasar pada balita di kampung cantilan kelurahan kagungan kecamatan kasemen kota serang tahun 2013. Jurnal Keperawatan, 1-6.

Supriatin, E. (2015). Hubungan pengetahuan dan dukungan keluarga dengan ketepatan waktu pemberian imunisasi campak di pasir kaliki bandung. Jurnal Ilmu Keperawatan, III(1), 1-10.

Wawan, A., \& Dewi, M. (2010). Teori \& pengukuran pengetahuan, sikap dan perilaku manusia. Yogyakarta: Nuha 